\title{
Sustainable community services for older people
}

\section{Commonwealth Journal of Local Governance}

Issue 22: 2019

http://epress.lib.uts.edu.au/ojs/index.php/cjlg

\author{
Chris Taylor \\ The Big Issue \\ Bath \\ United Kingdom \\ Email: Chris.Taylor@bigissue.com \\ Jed Donoghue \\ School of Social Sciences \\ University of Tasmania \\ Australia \\ Email: Jed.Donoghue@utas.edu.au
}
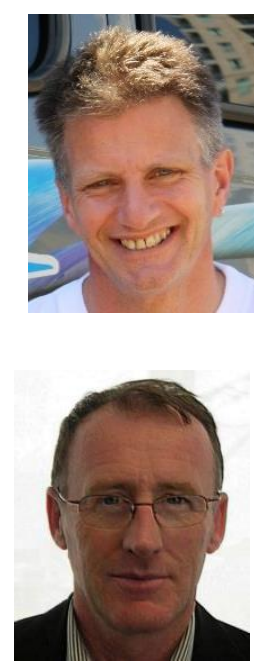

\begin{abstract}
This paper explores the sustainability of non-government organisations (NGOs) providing services to older people in the local government authority area of North Sydney. It identifies several key issues that can be used to assess the level of programme sustainability in the community sector. We suggest that government support is essential for the ongoing financial sustainability of community aged care services and that community-based organisations need to address a number of issues that will impact on their long-term sustainability. A good working relationship with local and state government is crucial for organisations to access community grants, donations and subsidised premises. The recruitment, training and retention of volunteers were some of the most important issues identified. Further, these NGOs will need to develop strategic plans that factor in sustainability indicators to address rental, recycling, transport, renewable energy and water costs to ensure that they have the capacity to pay for these utilities in the future.
\end{abstract}

\section{Introduction}

Non-government organisations (NGOs) are considered to be important for the quality of life of older people (Oppenheimer and Warburton 2014). However, smaller stand-alone community-based organisations have limited capacity to meet the needs of an ageing population (Skinner and Power 2011). This paper considers the sustainability of NGOs providing services to older Australians in the local government area of North Sydney. It will address two research questions: first, what are the main sustainability issues faced by smaller stand-alone community organisations; and how useful are existing sustainability indicators in providing a framework for NGOs to identify issues and plan for the future. 
The paper identifies issues that can be used to assess the sustainability of NGOs in the community aged care sector and could be used to implement strategic plans to ensure their future. ${ }^{1}$ We suggest that traditional stand-alone community-based, not-for-profit organisations will need to address a number of key issues that impact on their long-term sustainability. NGOs involved in the care of older people will need to source additional revenue streams to varying degrees and many will depend on volunteers. If NGOs did not undertake this care, some of the care burden would fall on local authorities. The literature suggests that the sustainability of community-based organisations will be vital for older people as they provide a range of opportunities for engagement and support in the community (Oppenheimer and Warburton 2014; VanSant 2003).

In Australia, services for older people are often provided by a range of small stand-alone communitybased organisations. Many have been created as a direct response to an unmet need in a particular community, such as Seniors Computer groups, Home and Gardening Maintenance Services and Men's Shed programmes, which have developed in Australia and the United Kingdom (Australian Men's Shed Association 2013). In the last 20 years these services have become more specialised as they respond to increased demands from a diverse population that is living longer and wishes to remain independent (Ringvall and Brunner 2013).

The Australian Commonwealth government is promoting concepts such as 'Ageing in Place' and 'Consumer Directed Care'. Ageing in Place is a term used to describe a person living in the residence of their choice, for as long as they are able, as they age. Whereas, Consumer Directed Care (CDC) is a model of service delivery that gives more choice and flexibility to consumers. Consumers who receive a Home Care Package have more control over the types of care and services they access and the delivery of those services, including who delivers the services and when they are delivered (Aged and Community Services Australia 2010). This includes being able to have any services or other support they might need over time as their needs change.

The government is also placing a greater emphasis on the accountability and efficiency of NGOs (Productivity Commission 2011). However, community-based organisations are becoming more dependent on annual government grants that necessitate a significant amount of time spent on reporting and complying with standards (Oppenheimer and Warburton 2014). Community organisations also rely heavily on volunteers who fill key service delivery and management roles as well as being 'housed' in subsidised rental premises (Oppenheimer and Warburton 2014; Shergold 2008). If rents were not subsidised the future sustainability of many community organisations would be undermined (Shergold 2008). In addition, many traditional community sector organisations are finding it increasingly difficult to attract new volunteers (Oppenheimer and Warburton 2014).

\footnotetext{
${ }^{1}$ An earlier version of this paper is available at as an Oxford Institute of Population Ageing Working Paper which can be viewed at www.ageing.ox.ac.uk/download/78
} 
Community-based organisations that provide community aged care services will need to adjust the way in which they provide services and how they market services to older people in the future. For example, over the last 20 years attitudes to residential aged care have changed (Ringvall and Brunner 2013). Older people want to reside for longer within their own home and local community. Governments have also recognised and encouraged the citizen's desire to remain at home. They have also supported the aged care sector with increased funding for community-based services and home care packages.

The Australian population is ageing as a result of sustained low fertility rates and increasing life expectancy. This trend is resulting in proportionally fewer children (less than 15 years of age) in the general population. The median age (the age at which half the population is older and half is younger) of the Australian population, for example, has increased by 4.7 years over the last two decades, from 32.4 years at 30 June 1991 to 37.1 years at 30 June 2011 (Australian Bureau of Statistics 2011). Over the next few decades, population ageing is projected to have significant implications for Australia in many spheres, including health, labour force participation, housing and demand for skilled labour (Productivity Commission 2011).

\section{Meaning of sustainability}

Sustainability developed as a concept in the late 1960s as an environmental term. Over time the concept has been broadened to include economic, social and corporate sustainability (McKenzie 2004). Terms such as the triple bottom line (social, environmental and financial), and sustainable development are now widely used in the private and community sectors (VanSant 2003; Productivity Commission 2011; United Nations 2015). Sustainable development is understood as development that meets the needs of the present generation without compromising the ability of future generations to meet their own needs (World Commission on Environment and Development 1987). This definition has been contested on the ground that it allows major developers to do what they want and pay lip service to future generations. De Vita and Fleming (2001) suggest that sustainable development is about managing change rather than a focus on the end goal and fixed outcomes, which can be at odds with government funding requirements.

Social sustainability is hard to quantify. McKenzie (2004) argues that indicators or measures are often developed within the context of the specific organisation or local community being studied and so their usefulness for comparative study is limited. He also suggests that in most instances local community organisations are often working towards achieving a certain level of social sustainability rather than viewing it as an end goal. However, he does argue that social sustainability is a positive condition and process within local communities.

The core of sustainability as a concept is that current decisions should not impair prospects for maintaining or improving future living standards. There is broad agreement that it is unfair to pursue 
policies that imperil the welfare of future generations who are unrepresented in any political or economic forum (Repetto 1986). We recognise that sustainability is a contested concept but define it here as "the ability of organizations to identify and manage issues that threaten their long-term viability" (see Kimaro and Nhampossa 2005, p. 274).

\section{Literature review}

The literature generally demonstrates that many NGOs are under-resourced. This paper provides an original contribution by identifying sustainability indicators that can be used by NGOs in their strategic planning. The role of NGOs is becoming more important in many developed nations as central governments try to reduce the size and cost of the public sector. The role of NGOs is also changing and expanding in English-speaking countries, which creates a need to increase their capacity and sustainable (VanSant 2003).

According to Korten (1987) NGOs have developed over time from basic community welfare providers, to small-scale community developers undertaking service delivery, to large national organisations focused on sustainable development (involving grassroots mobilisation and policy advocacy). As NGOs have become more complex there has been a proliferation of management tools for measuring organisational capacity and performance.

VanSant (2003) suggests that assessment tools usually offer a set of measurement categories or indicators. These are often qualitative so that measurement takes place along a defined descriptive scale. He clusters indicators into three categories based on organisational resources, organisational performance, and organisational sustainability. The authors are interested in organisational sustainability as it incorporates more forward-looking attributes, such as autonomy, learning capacity, and leadership. This category attempts to identify where an organisation is heading and how it will get there. This trajectory is heavily influenced by internal and external elements such as the quality of the organisation's leadership, capacity and relationship with government.

The nature of government policy and relationship with the NGO sector is determined by a number of factors including the type of political culture, ruling party agenda and the degree of political stability. Governments effectively control NGOs by co-opting them with a range of incentives or disincentives, by using either the carrot or the stick. However, governments often encourage NGOs to engage in gapfilling expensive service delivery activities. This is common in Australia, the UK and the United States of America where non-profit organisations play a large role in service delivery relating to homelessness, health services, and affordable housing (VanSant 2003).

Leadership is one of the most essential ingredients in organisational sustainability and probably the most important determinant of organisational performance. The key elements of leadership are vision, innovation, decisiveness, and a strong people orientation. The leader with a vision defines a clear and 
compelling agenda that is communicated effectively within the organisation and leads to a broad alignment and commitment. The importance of good leadership based on core organisational values and internal alignment to those values in an organisation cannot be overemphasised. These factors are the key to sustaining and enhancing an institution's capacity to meet its objectives (VanSant 2003).

The expectation that community-based organisation have good leadership, plus staff and volunteers who have the capacity and willingness to change in order to meet the needs of government and an ageing population is not a given. Many traditional community-based organisations struggle to manage and cope with change and are often resistant to it (Warburton et al. 2014). NGOs tend to focus on managing tight budgets and undertaking a balancing act between the needs of clients, volunteers and the government's policy agenda, which is aimed at promoting a more professional and contractual community sector (Skinner and Power 2011).

\section{Methodology}

This is a small study using qualitative analysis of several community aged care services in a local government area in North Sydney, Australia. For the purposes of this research 'small' communitybased organisations are defined by the fact that they rely mainly on volunteers and do not have a dedicated performance section (Jones 2012). The service providers interviewed were selected from eight aged care services in the local government area of North Sydney's Lower North Shore, which is covered by four local authorities and has a population of 192,000 (Australian Bureau of Statistics 2016). North Sydney has higher than average property prices and higher rents. It also has higher than average levels of older people aged $60+$ in the area, as $18.6 \%$ of the local population were aged over 60 years (Australian Bureau of Statistics 2016).

These aged care organisations rely mainly on volunteers and are not large enough to have a dedicated management unit and either have a voluntary management committee, or a head office in another region to provide direction. Detailed information was obtained from a review of all eight organisations' literature, from web sites and several visits to selected services. A total of six semi-structured interviews were undertaken with organisational staff or members of the voluntary management committee to discuss sustainability and service delivery issues.

This exploratory research is limited in scope due to the small sample size and focus on a local government area. A larger sample would provide more reliable information about the understanding of sustainability in the community aged care sector. However, the paper was informed by a range of sustainability and aged care literature. Informed discussion with community service providers and interviews with aged service workers also assisted with selecting sustainability indicators (see Table 1). The use of indicators to measure sustainability in community organisations can provide an organising framework. It also allows NGOs to identify the main sustainability issues faced by their organisation. 
It was evident that sustainability indicators need to be meaningful to the experience of community service providers to be useful in practice.

In North Sydney the three organisations selected for interviews reflect a range of activities, complexity and size. The Greenway Tenants Group, while not specifically intended for older people, was selected as it predominately serviced older people and was a relatively new organisation. The Neutral Bay Seniors were selected as they were well established and had been through a serious of changes over the past decade. The third group, Lower North Shore Community Transport, was selected as it was bigger in size, serviced more people and received funding from two different levels of government. It was also facing significant changes to its funding and operation.

Table 1: Small organisations that provide services for older people in North Sydney

\begin{tabular}{|c|c|c|}
\hline Organisation \& activity & Resources & Staffing \\
\hline $\begin{array}{l}\text { Waverton Hub } \\
\text { Information, activity and exercise group } \\
\text { (www.wavertonhub.com.au) }\end{array}$ & $\begin{array}{l}\text { Membership fees } \\
\text { Small grants } \\
\text { Fund-raising }\end{array}$ & 10 volunteers \\
\hline $\begin{array}{l}\text { Constant Companion } \\
\text { Alarm and assistance service } \\
\text { www willoughby.nsw.gov.au } 2008\end{array}$ & $\begin{array}{l}\text { Service fees } \\
\text { State \& local } \\
\text { Government funding }\end{array}$ & 2 employees \\
\hline $\begin{array}{l}\text { Lower North Shore } \\
\text { Home modification and maintenance service } \\
\text { www.lanecovenorthside.com.au/homemaintenance }\end{array}$ & $\begin{array}{l}\text { State government funding } \\
\text { Fees and donations }\end{array}$ & 5 employees \\
\hline $\begin{array}{l}\text { Men's Sheds x } 4 \\
\text { Founded } 2005 \\
\text { www.northsydney council/community services/ }\end{array}$ & $\begin{array}{l}\text { Council grant } \\
\text { Volunteers } \\
\text { Membership fees }\end{array}$ & $\begin{array}{l}6 \text { volunteers } \\
\text { Each council area has a } \\
\text { Men's shed }\end{array}$ \\
\hline $\begin{array}{l}\text { U3A Education } \\
\text { Founded pre } 1998\end{array}$ & $\begin{array}{l}\text { Fees } \\
\text { Grants }\end{array}$ & 5 Volunteers \\
\hline $\begin{array}{l}\text { Neutral Bay Seniors Community Centre } \\
\text { Seniors computers and activities } \\
\text { www.northsydney council/community services/ }\end{array}$ & $\begin{array}{l}\text { Membership } \\
\text { Council grants } \\
\text { Fees }\end{array}$ & 10 Volunteers \\
\hline $\begin{array}{l}\text { Lower North Shore } \\
\text { Community Transport } \\
\text { http://Insct.org.au/content/home }\end{array}$ & $\begin{array}{l}\text { Council \& state } \\
\text { Government grants } \\
\text { Sponsorship }\end{array}$ & $\begin{array}{l}5 \text { full-time staff } \\
\text { Part-time paid and } \\
\text { volunteer drivers }\end{array}$ \\
\hline $\begin{array}{l}\text { Greenway Tenants Group } 1998 \\
\text { Greenway Booklet Celebrating our home GTG and } \\
\text { Crow's Nest Centre } 2012\end{array}$ & $\begin{array}{l}\text { Fund-raising } \\
\text { Small grants } \\
\text { Coffee sales }\end{array}$ & 12 Volunteers \\
\hline
\end{tabular}

Source: Compiled by the authors

\section{Indicators of sustainability}

The Western Australian Council of Social Services (Barron and Gauntlett 2002) provides a good model of social sustainability for community organisations in Australia that is based on six principles: equity, diversity, interconnectedness, quality of life, democracy and governance. This model was designed for people working in marginalised and low-income public housing communities. Intergenerational relationships are also viewed as very important to ensure ongoing sustainability (Biggs and Lowenstein 2011). This view is supported by De Vita and Fleming (2001) who suggest that mentoring the next or 
'future' generations is an essential element of the social sustainability process for small communitybased organisations.

Sustainability indicators have been developed to cover all areas of activity and for many different purposes. In some cases, they can be used to justify funding and resource allocation, or as a tool for social planning and community needs analysis. Bell and Morse (2011) argue that policymakers need to be aware that not all sustainability indicators carry equal weight, and economic indicators tend to dominate discussions and analysis. Policymakers also need to take into account the type of community or organisation in which indicators are to be applied (Pepperdine 1998).

Edwards and Ingvarson (2013) researched responses from different local governments in Victoria and identified key indicators for measuring different areas of sustainability, such as the number of local volunteers, local procurement, self-financing ability and the use of sustainable energy and transport. When applied to smaller organisations the economic well-being translates into financial income and the level of independent income generated.

While the concept of sustainability is problematic because it relates to different conditions and circumstances, an objective of this study was to assess how sustainability indicators could be employed to better assist NGOs to provide services to older people in the future. Nine key areas of sustainability were initially identified as suitable indicators for community organisations (see Table 2).

Table 2: Proposed sustainability indicators for NGOs

\begin{tabular}{|l|l|l|}
\hline $\begin{array}{l}\text { Proposed sustainability } \\
\text { indicators }\end{array}$ & Measures & Issues \\
\hline $\begin{array}{l}\text { 1. Sustainable transport is used } \\
\text { and promoted }\end{array}$ & $\begin{array}{l}\text { Organisation promotes the use of } \\
\text { sustainable transport }\end{array}$ & $\begin{array}{l}\text { Proximately and use of public and } \\
\text { community transport }\end{array}$ \\
\hline $\begin{array}{l}\text { 2. Energy and recycling is } \\
\text { promoted }\end{array}$ & $\begin{array}{l}\text { Organisation promotes and } \\
\text { supports use of sustainable } \\
\text { energy systems and recycling }\end{array}$ & $\begin{array}{l}\text { Alternative energy use } \\
\text { Recycling activities }\end{array}$ \\
\hline $\begin{array}{l}\text { 3. Contribution and value of } \\
\text { volunteers is recognised }\end{array}$ & $\begin{array}{l}\text { Adequate levels of recruitment and } \\
\text { support for volunteers }\end{array}$ & $\begin{array}{l}\text { Adequate numbers of volunteers } \\
\text { Training and resourcing provided }\end{array}$ \\
\hline $\begin{array}{l}\text { 4. Access and inclusion is } \\
\text { promoted }\end{array}$ & $\begin{array}{l}\text { Membership reflects the diversity } \\
\text { of the community, is affordable } \\
\text { and easily accessible }\end{array}$ & $\begin{array}{l}\text { Strategies employed to engage } \\
\text { the local community }\end{array}$ \\
\hline $\begin{array}{l}\text { 5. Accountable and effective } \\
\text { business operations }\end{array}$ & $\begin{array}{l}\text { Corporate governance is effective } \\
\text { and appropriate for the } \\
\text { organisation }\end{array}$ & $\begin{array}{l}\text { Board membership } \\
\text { Qualifications and experience } \\
\text { Legal structure }\end{array}$ \\
\hline $\begin{array}{l}\text { 6. Independent income is } \\
\text { generated }\end{array}$ & Independent income is generated & $\begin{array}{l}\text { Level of independent income and } \\
\text { diversity of sources }\end{array}$ \\
\hline $\begin{array}{l}\text { 7. Employment opportunities are } \\
\text { created }\end{array}$ & $\begin{array}{l}\text { Employment opportunities for } \\
\text { older people are created }\end{array}$ & $\begin{array}{l}\text { Employment of older people } \\
\text { including part-time work }\end{array}$ \\
\hline 8. Resource sharing is promoted & $\begin{array}{l}\text { Opportunities for resource sharing } \\
\text { are created and developed }\end{array}$ & $\begin{array}{l}\text { Resources are shared or jointly } \\
\text { owned with other organisations } \\
\text { and age groups }\end{array}$ \\
\hline $\begin{array}{l}\text { 9. Participation and empowerment } \\
\text { is encouraged }\end{array}$ & $\begin{array}{l}\text { Service organised as a social } \\
\text { enterprise }\end{array}$ & $\begin{array}{l}\text { Level of participation by older } \\
\text { people }\end{array}$ \\
\hline
\end{tabular}

Source: Compiled by the authors 


\section{Key findings}

Structured interviews, service visits and the desktop audits of the organisations' literature provided a rich source of service data. The data provided a number of findings and allowed an understanding of the issues relevant to community-based organisations. In all three community-based organisations it was evident that there were sustainability issues that needed to be addressed (see Table 3).

Table 3: Significance of sustainability indicators for NGOs

\begin{tabular}{|l|l|}
\hline \multicolumn{1}{|c|}{$\begin{array}{c}\text { Significance of sustainability } \\
\text { indicators for NGOs }\end{array}$} & \multicolumn{1}{c|}{ Key findings } \\
\hline $\begin{array}{l}\text { 1. Volunteers are recruited and } \\
\text { recognised }\end{array}$ & $\begin{array}{l}\text { Recruitment and support of volunteers was considered essential } \\
\text { by all organisations }\end{array}$ \\
\hline 2. Independent income is generated & $\begin{array}{l}\text { Local government grants and an income independent (from } \\
\text { government) was considered essential by all organisations }\end{array}$ \\
\hline $\begin{array}{l}\text { 3. Accountable and effective business } \\
\text { operations }\end{array}$ & Financial and legal expertise were valued by all organisations \\
\hline $\begin{array}{l}\text { 4. Sustainable transport is used and } \\
\text { promoted }\end{array}$ & All services were located near to public transport services \\
\hline $\begin{array}{l}\text { 5. Access and inclusion is promoted } \\
\text { 6. Participation and empowerment is } \\
\text { encouraged }\end{array}$ & $\begin{array}{l}\text { There was good mobility access to all the organisations and two } \\
\text { organisations had service users on their management committee }\end{array}$ \\
\hline 7. Resource sharing is promoted & $\begin{array}{l}\text { Participation and empowerment was encouraged by } \\
\text { organisations to varying degrees }\end{array}$ \\
\hline 8. Employment opportunities are created & $\begin{array}{l}\text { Resource sharing was valued by all services but only practised } \\
\text { by two organisations }\end{array}$ \\
\hline 9. Energy and recycling is promoted & $\begin{array}{l}\text { There were few employment opportunities in the majority of the } \\
\text { organisations }\end{array}$ \\
\hline
\end{tabular}

Source: Compiled by the authors

The most significant issue was the ongoing recruitment and retention of volunteers. In one of the organisations volunteers were supported with bus fares, food or expenses. Two of the organisations held recognition events to celebrate the contribution of volunteers. There was general recognition that the ongoing recruitment and support of volunteers was essential to the survival of the organisation. This included the use of volunteers with financial and legal expertise on management committees.

Local government support in respect of grants, donations and building use was evident for all the organisations. This was also recognised as an essential feature for the ongoing financial sustainability of the organisation. At the same time all organisations recognised the need for diverse sources of income and resources. All organisations had varying levels of independent income.

In all the organisations there was little interest or awareness of environmental sustainability issues such as renewable energy systems. However, this can be partly explained by the fact that in all of the organisations the energy bills were paid by a third party. Two organisations did provide for community gardening and some recycling activities. All the organisations were located near public transport and made use of local community transport services. 
The organisations all reported positive relationships with other community-based organisations and were prepared to resource share and enter into resource sharing arrangements. However, there was limited understanding of social procurement for the benefit of the local community, the only instance being the purchase of vehicle servicing from the local council to maintain and support local employment.

Intergenerational activities were promoted in all organisations, often as a response to an unmet need in the organisation. The general response to promoting and hosting intergenerational activities was positive. All of the organisations were accessible to people with limited mobility. Information about the service was provided in languages other than English in all of the organisations.

\section{Discussion}

Government support is essential for the ongoing financial sustainability of community aged care services. Government support allows NGOs to build their capacity and reduce the care burden on the state. Many NGOs will need to adjust the way in which they provide and market their services to the older population. In the last 25 years attitudes to residential and community aged care have changed. Increased numbers of older people are expected to remain within their own home and local community. The Australian government has recognised and encouraged the trend for older people to remain at home. Governments have supported the aged care sector with increased funding for community-based services and comprehensive aged care packages.

The Productivity Commission Report (2011) identified significant challenges facing the Australian aged care system including:

- Increased numbers of older people in the community

- An increasing number of age-based diseases and disabilities

- Rising community expectations of the type of aged care

- Community concerns about the variability of aged care

- Decline in the number of aged carers

- A need for more nurses and personal care workers with enhanced skills.

Government changes to the retirement age mean that older people who would normally have volunteered after retirement many now remain in work, or re-join the workforce. This will have the effect of reducing the supply of volunteers to community-based organisations. Aged care services will need to compete for volunteers and need to develop recruitment and support plans in the future (Warburton et al. 2014; Kerr and Carson 2010). This may result in the development of social enterprises and part-time work for older people who would normally have volunteered. 
Most community-based organisations rely on local or state government grants and donations to remain financial sustainable. According to Smedley (2014) community organisations that rely heavily on volunteers and government grants will need to form partnerships with other NGOs or the private sector to increase their capacity and become more self-reliant. Resource sharing with other organisations was considered to be a more attractive option than mergers or takeovers due to the associated loss of service identity.

NGOs did not consider the cost of energy to be a significant sustainability issue, as their energy costs were usually included in the subsidised rent. If these rental arrangements changed community organisations would be faced with a major cost increase. Power saving, recycling practices, transport usage, plus water and energy audits would be worthwhile undertakings for most community organisations (Dhakal 2012).

Age UK provides a good example for stand-alone community organisations in Australia. It is a national network of local organisations providing programmes for older people. It promotes itself as a 'brand' and has a record of rising money via donations and marketing, such as the selling of discount insurance to older people. This model promotes resource sharing and activities such as luncheon clubs that promote service sustainability.

Sustainable Resource Organisations (SROs) that support small community organisations have been developed in parts of Australia. For example, in Sydney the Social Enterprise Resource Organisation (Sydney Social Enterprise) assists people in Western Sydney to set up and develop social enterprise organisations. Their main role is to provide training sessions in business development, applying for funding and the running of a small social enterprise.

\section{Conclusion}

This paper suggests a number of ways that NGOs can increase their self-reliance and highlights the need for additional revenue streams. As an increasing number of older people remain in their home the demands on the age care system will continue to grow. At the same time there will be fewer volunteers to look after older people as the retirement age is pushed back by government. There could also be a shortage of skilled workers in the aged care sector unless there is better pay and an expansion of accredited courses to encourage people to join the work force.

There are several resourcing issues that impact on the long-term sustainability of aged care services. Not surprisingly, the recruitment of skilled volunteers is regarded by NGOs as very important because they undertake service delivery and management activities. The capacity to source and support volunteers will be crucial for the future sustainability of many community-based organisations. 
A good working relationship with local and state government is crucial for organisations to access community grants, donations and subsidised premises. Community organisations have limited interest in renewable energy when their power bills are paid for by local government. If these organisations were faced with bills for commercial power or water it would have a negative impact on their financial ability to remain sustainable. NGOs will need to develop strategic plans that factor in sustainability indicators to address rental, recycling, transport, renewable energy and water costs to ensure that they have the capacity to pay for these utilities in the future.

\section{Declaration of conflicting interest}

The authors declared no potential conflicts of interest with respect to the research, authorship, and/or publication of this article.

\section{Funding}

The authors received no financial support for the research, authorship, and/or publication of this article.

\section{References}

Aged and Community Services Australia (2010) Guiding principles for consumer-directed care. South Melbourne: ACSA.

Australian Bureau of Statistics (2011) Population by age and sex, Australian States and Territories. Canberra: Australian Government Publication. Available at: www.abs.gov.au/ausstats/abs@.nsf/0/AE3CAF747F4751CDCA2579CF000F9ABC?OpenDocument [Accessed 5 January 2020].

Australian Bureau of Statistics (2016) Census statistics. Canberra: Australian Government Publication.

Australian Men's Shed Association (2013) Background information. Available at: www.mensshed.org

Barron, L. and Gauntlett, E. (2002) Model of social sustainability. Housing and Sustainable Communities Indicators Project. Perth: Western Australian Council of Social Service.

Bell, S. and Morse, S. (2011) Sustainable Development Indicators: The tyranny of methodology revisited. The Journal of Sustainable Development, 6 (1), 222-239.

Biggs, S. and Lowenstein, A. (2011) Generational intelligence, a critical approach to age relations. London: Routledge.

De Vita, C. and Fleming, C. (2001) Building capacity in non-profit organisations. Washington DC: The Urban Institute.

Dhakal, S.P. (2012) Regional sustainable development and the viability of environmental community organisations: Why does inter-organisational social capital matter? Third Sector Review, 18 (1), 7-27.

Edwards, S. and Ingvarson, C. (2013) Perceptions and indicators of sustainability. Melbourne: Melbourne Sustainable Society Institute, University of Melbourne.

Jones, H. (2012) Seeing the difference: Measuring the impact of small community organisations. London: Goldsmiths, University of London and Voluntary Action Islington.

Kerr, L. and Carson, E. (2010) Contractualism, workforce-development and sustainability in the communityservices sector in Australia. Third Sector Review, 16 (1), 69-86.

Kimaro, H.C. and Nhampossa, J.L. (2005) Analyzing the problem of unsustainable health information systems in less-developed economies: Case studies from Tanzania and Mozambique. Information Technology for Development, 11 (3), 273-298. https://doi.org/10.1002/itdj.20016 
Korten, D.C. (1987) Third generation NGO strategies: A key to people-centered development. World Development, 15, 145-159. https://doi.org/10.1016/0305-750x(87)90153-7

McKenzie, S. (2004) Social sustainability towards some definitions. Hawke Research Institute Working Paper Series no. 27. Magill, South Australia: Hawke Research Institute, University of South Australia.

Oppenheimer, M. and Warburton, J. (eds.) (2014) Volunteering in Australia. Sydney: Federation Press.

Pepperdine, S. (1998) Making people's values count: Measuring rural community sustainability. In $18^{\text {th }}$ Annual Meeting of the International Association for Impact Assessment, 19-24 April 1998, Christchurch: New Zealand.

Productivity Commission (2011) Caring for older Australians: Overview. Report No. 53, Final Inquiry Report. Canberra: Productivity Commission.

Repetto, R. (1986) World enough and time. New Haven: Yale University Press.

Ringvall, K. and Brunner, J. (2013) Sustainable housing in aged care facilities. In Conference Proceedings State of Australian Cities Conference. Sydney: State of Australian Cities Research Network.

Shergold, P. (2008) Towards a more effective and sustainable community services system. Discussion Paper. Melbourne: Victorian Council of Social Services.

Skinner, M. and Power, A. (2011) Voluntarism, health and place: Bringing an emerging field into focus. Health \& Place, 17 (1), 1-6. https://doi.org/10.1016/j.healthplace.2010.09.001

Smedley, T. (2014) The voluntary sector is dead, long live the voluntary sector. Guardian Professional, 6 January 2014.

United Nations (2015) Sustainable Development Goals. Available at: https://sustainabledevelopment.un.org/sdgs [Accessed 7 December 2019].

VanSant, J. (2003) Challenges of local NGO sustainability. Key Note Address USAID/PVC-ASHA Annual PVO Conference, 14 October, Duke Centre for International Development, Duke University.

Warburton, J., Oppenheimer, M. and Moore, M. (2014) Volunteering in traditional and social welfare organisations: Current challenges and opportunities. Sydney: Federation Press.

World Commission on Environment and Development (1987) Our common future. Oxford: Oxford University Press. 